\title{
THE HAEMOCYTES EFFECT OF THE PAENIBACILLUS LARVAE SPORES IN ADULT HONEY BEE WORKERS (APIS MELLIFERA L.)
}

\author{
ZIDAN, E.W. ${ }^{1}$, AZZA T. ASHOUR ${ }^{2}$ and SAHAR Y. ABDEL-AZIZ ${ }^{2}$ \\ 1. Bee Research Dept., Plant Protection Research Institute, Agriculture Research Center \\ Dokki, Giza, Egypt ${ }^{1}$. \\ 2. Economic Entomology and Pesticides Dept., Faculty of Agriculture, Cairo University ${ }^{2}$
}

(Manuscript received 20 February 2018)

\begin{abstract}
$\mathrm{T}$ his work aimed to study the pathogenic effect of the Paenibacillus larvae spores on adult honey bee workers to explain the death many of them in the communities affected by American foul brood disease. This work was done through two methods; first injected the microbial suspension in the intersegmental membrane of the back lymph cavity of adult bee workers. The blood films were done after 1, 2, 4\&12 hrs. beginning of the injection method, while with the feeding method it carried out after one, two and three months. During the first period of the microbial injection one hour later an elongation and minor abnormalities were occurred in some blood cells. The second stage began after $2 \mathrm{hrs}$. is characterized by loss of the blood cells dye strength. After 4 hrs. the third stage is characterized by increase atrophies of some blood cells. The fourth and final stage after $24 \mathrm{hrs}$. abnormalities in most blood cells with sharp decline in their numbers clearly. This stage considers beginning end of the blood cells alive and the rapid death of most of bee workers was detected. This experiment affirms that adult bee workers can be affected by the Paenibacillus larvae spores. That may be one reason of death bee workers in infected bee colonies by the American foul brood disease.
\end{abstract}

Keywords: Honey bee, Haemocytes, Paenibacillus larvae.

\section{INTRODUCTION}

Bees live in the world in a complex interaction with their environmental condition. In order to understand one of these interventions between pathological and physiological process is indispensable particularly if their effects reflects on the honey bee colony alive. One of these interposition factors is the American foul brood disease (AFB) which is one of the most jeopardy bacterial attacking honey bees colonies causing a decline in the bee population and colony vigor (Generisch et al., 2006). Although several antibiotics were used for controlling the microbial infection (Genersch and Otten, 2003), may several problems still affecting the honey bee lifespan and colony products (Genersch 2010). Despite the pathogen mainly infected honey bee larvae, it can seriously injured adult bees reflects on the cellular immunity responses and most physiological organs (Szymas and Jedruszuk, 2003). One of subjects that worry researchers and beekeepers is ambiguity of gradually death honey bee members and rapid replacement honey bee queens. May the circular system be injured by different pathogens particularly by the (AFB). Therefore, the present work 
aims to clarify the pathogenic role of the Paenibacillus larvae spores on the blood cells as a general physiological factor in side and in another side to clarify other defensive behavior can the workers take during different attack methods. Through microbial feeding method a gradually decrease in the blood cells were detected in the haemolymph of infected honey bee workers during three months of completely death bee colonies.

\section{MATERIALS AND METHODS}

The present work was done at the department of Apiculture, Plant Protection Research Institute, Agriculture Research Center, Dokki, Giza, Egypt. Nine of honey bee colonies were conducted for this study and divided into three groups one for injection the paenibacillus larvae spores

which caused the American foul brood disease to honey bees. The $2^{\text {nd }}$ was feeding adult bee workers by the microbial through sugar solution. The last for the control not received any treatments.

\section{1- Isolation and purification of the Paenibacillus larvae spores}

This method was done according to Nordstrom and Fries (1995) and Anderson (1990) techniques at Fac. of Science. El-Mansoura Univ.

\section{2- Microbiological assays}

Bacterial smears were microscopically examined after treated with Gram stain according to Shimanuki and Knox (1991).

\section{3- The inoculation with $\boldsymbol{P}$. larvae Spores}

The following techniques were carried out;

\subsection{Injection method}

$10 \mu \mathrm{l}$ of the of $P$. larvae spores suspension with concentration of $\left(6 \times 10^{6}\right.$ $/ 1 \mathrm{ml}$ ) was added to $100 \mathrm{ml}$ of the saline solution ( $\mathrm{Na} \mathrm{Cl} 0.09 \%$ ), then $4 \mu \mathrm{l}$ of them was injected into healthy nursing honey bee workers through back lymph cavity between intr segmental membrane (about fifty samples / colony) (Casteels et al.,1989). The blood films were done after 1, 2,4,24 hrs. of injection initiation from treated and non treated bee workers with the pathogen.

\subsection{Feeding method}

$10 \mu \mathrm{l}$ of the microbial suspension of $P$. larvae spores with concentration of $\left(6 \times 10^{6}\right.$ spores $\left./ 1 \mathrm{ml}\right)$ was added to $100 \mathrm{ml}$ of the saline solution ( $\left.\mathrm{Na} \mathrm{Cl} 0.09 \%\right)$ and sweated with the sucrose then feeding honey bee colonies using spraying method between bee combs ( $10 \mathrm{ml} /$ colony / one time). The blood films of nursing honey bee workers were done after 1, 2 and 3 months of treatments.

\section{4- Blood smear films}

Blood films were prepared and pigments with Gimsa's stain for each treatment (Nappi and Streams, 1969). 


\section{RESULTS AND DISCUSSION}

The classification of the blood cells in honey bee workers was done according to Zakaria (2011). The haemolymph of the honey bee workers inoculated with the Paenibacillus larvae spores showed different features towards the microbial infection as follows;

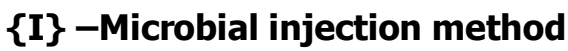

\section{I- One hour later of treatment}

Through injected the microbial suspension of the pathogen (Paenibacillus larvae) into back cavity lymph of adult honey bee workers a different features against the bacterial infection were detected as follows;

1-Neutrophile: Neutrophile cells take different shapes towards bacterial invasion in comparison to control one Fig. 1(B). Whereas expansion in the outer surface wad detected as shown in Fig. 1(C). Also laceration in the general cells components (Fig. 1-D).

2- Spindle shaped cells: Dwarf in the Spindle shaped cells due to bacterial infection as shown in Fig. (1-F) was detected in comparison to healthy one (Fig.1 E).

3- Macronucleocytes: They are the most famous as a phagocytes Fig.1(G). In Infected state this cell showed slight to sharp elongation shaped in their outer surface (Fig.1-H).

4- Plasmatocyte: Plasmatocyte cells lost parts of their components (Fig. 1-J) in comparable to healthy one (Fig.1-I).

\section{II -Two hours later of treatment}

1- Proleucocytes: Proleucocyte cells showed flabbiness in the outer cytoplasm tissue (Fig.2B) inverse to control one (Fig.2A).

2- Hyalinocytes: The cytoplasm of the Hyalinocyte cells showed more faint stain (Fig.2D) adverse to control one (Fig. 2C).

3- Basophile cells: The Basophilic cells showed rupture in their outer membrane (Fig.2F) and lost of force pigments (Fig. 2G) opposite with healthy one (Fig.2E).

4-Other blood cells: Other blood cells were not severe affected as the pervious mention. This period is characterized by increase the transparency of the cell cytoplasm stain.

\section{III - Four hours later of treatment}

1- Basophile cells: In spite of the damage of the Basophile cells was detected (Fig.2H). The most of them was still healthy as that of Fig. (2E).

2- Other blood cells: Other blood cells were affected by different degrees. This period is characterized by increase the initiation of dwarf cells. 


\section{IV- Twenty four hours later of treatment}

After 24 hours of treatment a sharp deformation in most of the blood cells with force decline in their numbers was detected reach to $90 \%$ particularly with the Hyalinocytes. This is considered end of the blood cells alive. Most of the bee workers were dead after $24 \mathrm{hr}$. of the microbial injection period.

\section{\{II $\}$ - Microbial feeding method}

Through microbial feeding method a gradually decrease in the blood cells were detected in the haemolymph of infected honey bee workers during three months of completely death bee colonies. The Spherulocyte cells showed more activity in state of the bacterial infection as shown in Fig. $(3-A, B)$. The Oenocytoids cells showed abnormal state (Fig.3 C, D), whereas Spindle cells showed dwarf shape (Fig.3 E,F). Despite of a sharp decrease in the blood cells, little of infected bee workers were still alive before one month of the completely dead bee colony.

Generally, it could be concluded that during the first period of the one hour of the microbial injection an elongation and minor abnormalities were occurred in some blood cells. After 2 hrs. the second stage began, which is characterized by loss of the blood cell dye strength. After $4 \mathrm{hrs}$. the third stage is characterized by increase dwarfism of the blood cells. The $4^{\text {th }}$ final stage after $24 \mathrm{hrs}$. abnormalities in most blood cells with sharp decline in their numbers was detected. The last stage consider beginning end of the blood cells and the rapid death of most of bee workers. This experiment affirm that adult bee workers can be affected by the Paenibacillus larvae spores. That may be one reason of death adult bee workers in infected bee colonies by the American foul brood disease.

Paenibacillus larvae spore's effects on the blood cells of immature and mature honey bee workers were detected by Zakaria (2007). Papadopoulou et al., (2003) reported that blood cells of the honey bees artificially infected with Pseudomonas aeruginosa cause septicemia showed not significantly effect on the total and differential haemocyte counts. Also, deficient nutrition can impair immune function and increase the susceptibility of individuals to disease as suggested by Alaux et al., (2010). Julia et al., (2017) reported that the toxin Plx2A is an important virulence factor of Paenibacillus larvae, the etiological agent of American Foulbrood, the most destructive bacterial disease of honey bees. Plx2A induced actin cytoskeleton reorganization while in insect cells, vacuolization and the occurrence of bi-nucleated cells was observed. The latter is indicative of an inhibition of cytokinesis. All these cellular effects are consistent with Plx2A inhibiting the activity of RhoA by covalent modification. That review clarifies the rupture occurred to the blood cells resultd the exposure to the pathogen (Paenibacillus larvae). Michel (2018) reported that toxins are powerful pathogenicity factors produced by certain bacteria, fungi, animals, and plants which mediate drastic interactions of these pathogens on the organism host. 
Notably, bacterial toxins were the first compounds which were identified as responsible for severe bacterial diseases in animals. Endotoxins are membrane compounds of Gram-negative bacteria which elicit an inflammatory response in host. Gilliam (1978), suggested that the microorganisms could have entered the queen during copulation.

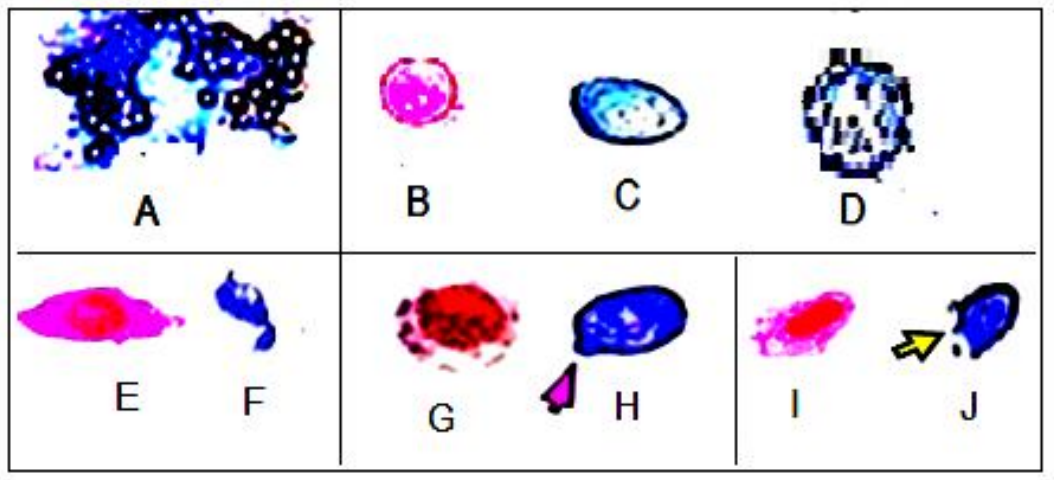

Fig.1 Paenibacillus larvae spores and blood cells of adult honey bee workers one hour later of the bacterial injection $(x-400)$.
A. Paenibacillus larvae spores.
B. Healthy Neutrophile cell.
C. Elliptical of the Neutrophile cell.
D. Indentation in the outer surface of the Neutrophile cell.
E. Spindle shaped cell as normal one.
F. Spindle cell a dwarf as bacterial infection.
G. Macronucleocytes in normal state.
$\mathrm{H}$. Macronucleocytes with slight elongation due to bacterial infection.
I. Plasmatocyte cell in healthy state.
G. Damage in the Plasmatocyte cell resulted of $P$. larvae infection.

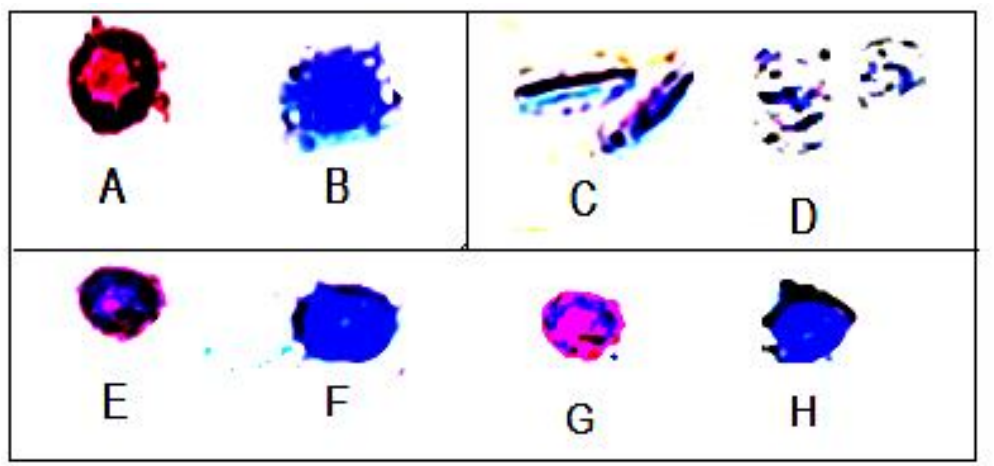

Fig. 2 Blood cells of adult honey bee workers in normal and bacterial infection state after 2,4 hrs. of the microbial injection.(x-400).
A. Proleucocyte cells.
C. Hyalinocytes of transparent cytoplasm in healthy one.
D. Faint stain of infected Hyalinocytes.
E. Basophile cells in normal state.
F. Basophile cells showed extensions in the outer membrane.
G. Basophile cells showed basophilic faint stain.
$\mathrm{H}$. Damage the basophile cells after $4 \mathrm{hrs}$. of infection state

B. Flabbiness in the outer surface of the Proleucocyte cells in infection state. 


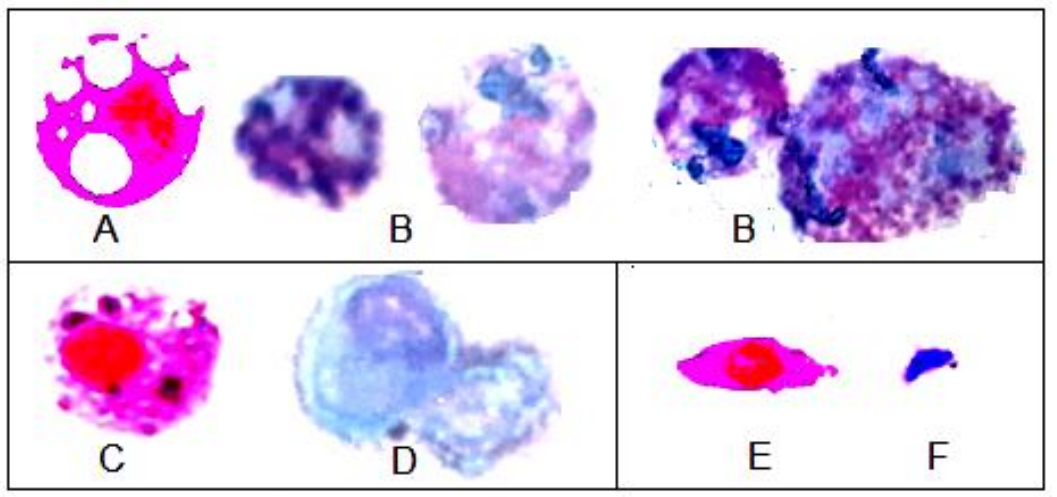

Fig.3.Blood cells of adult honey bee workers through inoculation the Paenibacillus larvae spores in feeding syrup $(x-400)$.

A. Spherulocyte cells in normal state.

B. Spherulocyte cells showed more activity in the bacterial infection.

C. Oenocytoids in healthy state.

D. Oenocytoids in the infection showed deformation.

E. Spindle shaped cells in normal state.

F. Dwarf Spindle shaped cells in the microbial infection.

\section{REFERENCES}

1. Alaux, C.; Ducloz , F.; Crauser, D. and Le Conte, Y. 2010. Diet effects on honey bee immunocompetence. Biol. Lett. 6(4):562-565.

2. Anderson, D. L. 1990. Pets and pathogens of the honey bees (Apis mellifera L.) in Fui. J. Apic. Res. 29(1): 53-59.

3. Casteels, P.; Ampe, C.; Jacobs Vaeck, M. and Tempst, P. 1989. Apidaecins: antibacterial peptides from honeybees. EMBO J. 8 (8)2387-2391.

4. Genersch, E. 2010. American foul brood in honey bees and its causative agent, Paenibacillus larvae. J. Invertebr. Pathol.103:510-519.

5. Genersch, E. and Otten, C. 2003. The use of repetitive element PCR fingerprinting (rep-PCR) for genetic sub typing of German field isolates of paenibacillus larvae subsp. larvae. Apidologie, 34: 195-206.

6. Genersch, E.; Forsgren, E.; Pentikäinen, J. ; Ashiralieva, A. ; Rauch, S.; Kilwinski, J. and Fries, I. 2006. Reclassification of Paenibacillus larvae sub species, Pulvifaciens and Paenibacillus larvae sub species larvae as Paenibacillus larvae without subspecies differentiation,56 (3):501-511.

7. Gilliam, M. 1978. Bacteria belonging to the genus Bacillus isolated from selected organs of queen honey bees Apis mellifera. J.Invertebr.Pathol.31:389-391. 
8. Julia, E. ; Fünfhaus , A.; Knispel , H.; Krska, D.; Ravulapalli , R.; Heney K. A. ; Lugo , M. I. R.; Merrill, A. and Genersch, E. 2017. Characterization of thetoxin Plx2A, a RhoA targeting ADP ribosyltransferase produced by the honey bee pathogen Paenibacillus larvae. Environomal microbiology banner V.19, 12:51005116.

9. Michel, R. Popoff. 2018. Bacterial Toxins" Section in the Journal Toxins: A Fantastic Multidisciplinary Interplay between Bacterial Pathogenicity Mechanisms, Physiological Processes, Genomic Evolution, and Subsequent Development of Identification Methods, Efficient Treatment, and Prevention of Toxigenic Bacteria.Toxins, 10, 44.

10. Nappi, A.J. and Streams, F.A. 1969. haemocytic reactions of Drosophila melanogaster to the parasites Pseudocoila mellipes and P.bochei. J. of Insect Physiol., 15:1551-1566.

11. Nordström, S. and Fries, I. 1995. A comparison of media and cultural conditions for identification of Bacillus larvae in honey. J. of

Apic. Res., 34: 97-103.

12. Papadopoulou-K. K.; Iliadis, N. and Liakos, V. 2003. Haemocyte changes in honey bee (Apis mellifera L.) artificially infected by Pseudomonas aeruginosa. Apidologie, 24: 81-86.

13. Shimanuki, H. and Knox, D. A. 1991. Diagnosis of honey bee diseases. Book Agriculture Handbook, Agricultural Research Service, US Department of Agriculture, $53 \mathrm{pp}$.

14. Szymas, B. and Jedruszuk, A. 2003. The influence of different diets on blood cells of adult worker honey bees, Apis mellifera. Apidologie, 34: 97-102.

15. Zakaria, M. E. 2007. The cellular immunity responses in the haemolymph of honey bee workers infected by American foulbrood disease (AFB). J. Appl. Sci. Res., 3(1): 56-63.

16. Zakaria, M.E. 2011. Tolerant honey bee colonies to infection by American foul brood disease using aromatic oils. Egypt. J. Agric. Res., 89 (4): 1341 -1352. 


\title{
التأثير الخلوي لجراثيم Paenibacillus larvae في
}

\section{شغالات نحل العسل البالغة (Apis mellifera L.)}

\author{
إيهاب وفيق محمود زيدان1، عزة توفيق عاثور22 ، سحر ياسين عبد العزيز2 \\ 1. قسم بحوث النحل - معهـ بحوث وقاية النباتات - مركز البحوث الزراعبة - الدقى - جيزة - مصر \\ 2. قسم الحشرات الإقتصادية والمبيدات - كلية الزراعة - جامعة القاهرة
}

يهذف هذا البحث إلى در اسة التأثثر الخلوي لجر اثيم Paenibacillus larvae المسببة لمرض

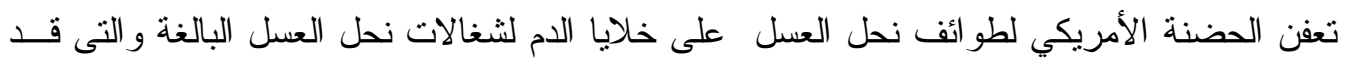
تكون أحد أسباب هلاك الطائفة ، وقد تم ذلك من خلال العدوى الصناعية بجر اثثم المسبب المرضي

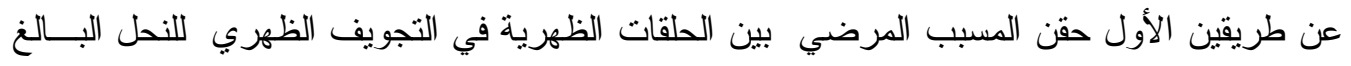

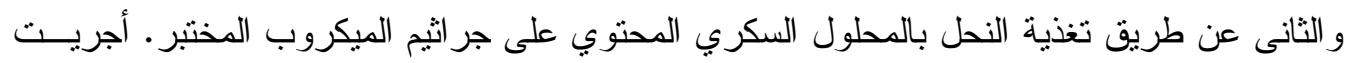

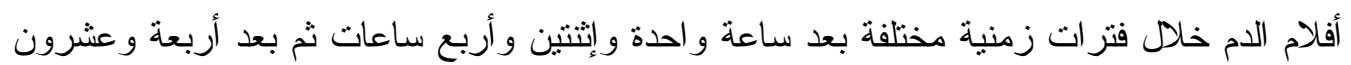

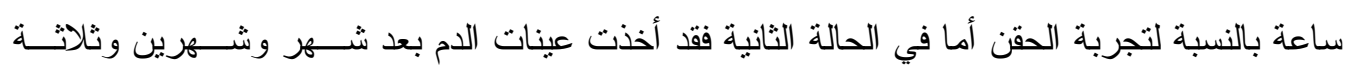

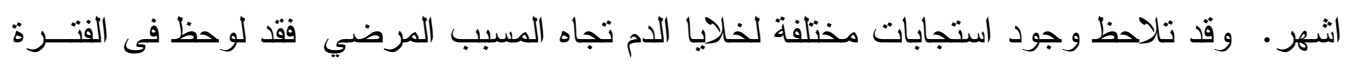

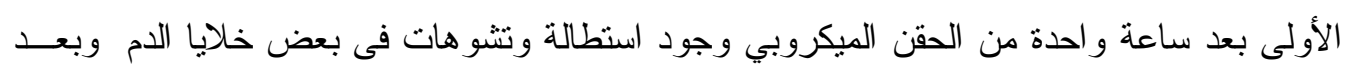

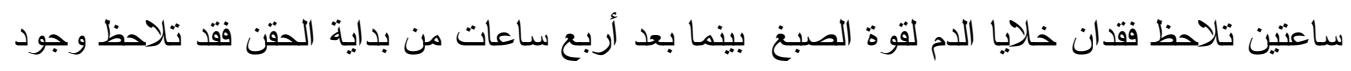

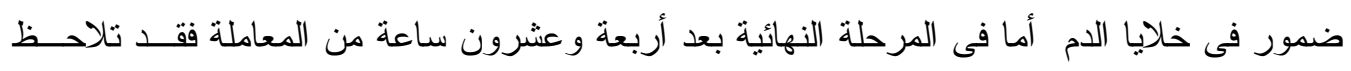

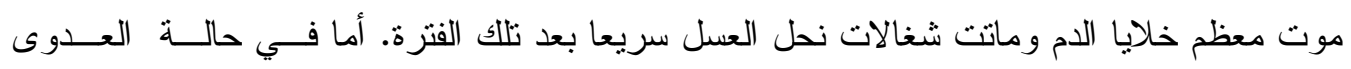

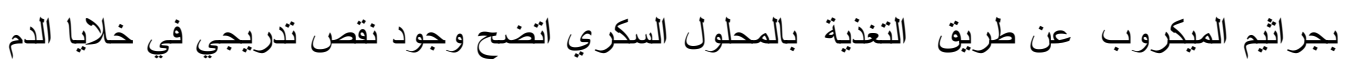

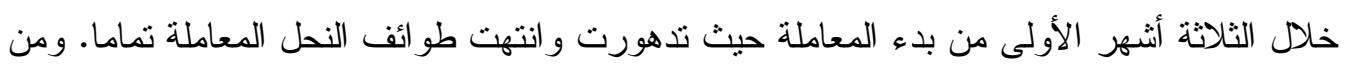
نتائج هذه التجربة يتضح نأثرخلايا دم النحل البالغ بالمسبب المرضي الذى قد يكون أدهاء أحد أسباب انهيار

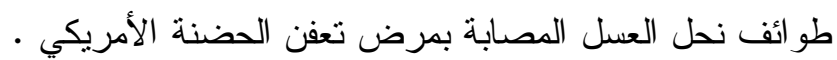

